\title{
Review: Synthesis of Urea in Several Methods
}

\author{
Asep Rizki Pradana *, Asep Royani, Kiki Zulfikri, Nabila Tuffahati, Rahma Zulfa Azzahra, Tasya Qori \\ Amini and Asep Bayu Dani Nandiyanto
}

Dr. Setiabudi No.229, Bandung City, West Java, Department of Chemistry Education, Mathematics and Science Education Faculty, Universitas Pendidikan Indonesia, Indonesia

\begin{abstract}
Urea $\left(\mathrm{CO}(\mathrm{NH})_{2}\right)$ is one of the compositions in making fertilizer. Fertilizer is crucial, especially for plant growth (affecting plant fertility). If a plant had urea fertilizer on the soil, nitrogen in the fertilizer releases quickly, and it will cause environmental pollution. Therefore, many studies want to develop urea fertilizer to be more efficient to use. The purpose of this review is to find the most appropriate method for the efficient use of urea as seen from the material used, the technique used, and the results obtained. This review shows that the most appropriate method is the slow release method with $\mathrm{NaOH}$ and fly ash ingredients. Because this method can increase the effective utilization of urea, reduce environmental pollution, and be relatively more straightforward, the raw material is more affordable and spread widely in the market.
\end{abstract}

Keywords: Methods; Nitrogen; Slow Release.

\section{Introduction}

Nitrogen is an essential nutrient in plants that function in protein formation, chlorophyll synthesis, and metabolic processes ${ }^{1}$. Nitrogen is also one of the macronutrients required by plants. Urea is widely used as fertilizer due to its high nitrogen content $( \pm 46 \%)$. However, as much as $50-60 \%$ nitrogen is lost through leaching, decomposition, and evaporation of ammonia ${ }^{2}$. Although nitrogen losses can be reduced by re-fertilization in one planting season, this method is inefficient because farmers' production costs will be higher.

Urea is a polar, highly soluble in water, and chargeneutral molecule, with oxygen and two nitrogen atoms serving as hydrogen bond acceptors. Two amino functions provide a total of four hydrogen bonds for donation. The molecular formula is $\mathrm{CO}\left(\mathrm{NH}_{2}\right)_{2}$; the molecular mass is $60.06 \mathrm{~g} / \mathrm{mol}^{3}$.

Based on Dazmiri, MK et al., 2019, formaldehyde to urea has 3 initial molar ratios $\mathrm{F} / \mathrm{U}$ of $1.9,2.1$, and 2,3 resin synthesis have been examined in this work ${ }^{4}$. While in Dorieh A. et al., 2018 initial molar ratio formaldehyde $\mathrm{F} / \mathrm{U} \sim 5$ and 4.3 molar ratio ${ }^{5}$.
Nitrogen in agricultural and plantation activities is met through a fertilization process, such as urea. Excess use of urea fertilizer in agricultural and plantation activities results in environmental pollution. Urea fertilizer only provides a small part of the nutrients that plants absorb, and the rest is wasted in the environment ${ }^{6}$.

Based on the researches, $\mathrm{CO}\left(\mathrm{NH}_{2}\right)$ various methods can produce 2 , such as slow-release fertilizer with multiple materials (chitosan matrix; fluidized bed; coal fly ash and $\mathrm{NaOH}$; cooking oil and paraffin; PVA polymer; aldehyde with 3-4 atoms of carbon), gasification with the help of temperature regulation, nuclear cogeneration, the nuclear steam reforming process, spectrophotometry, and graphene preparation.

\section{Urea Fertilizer Synthesis Methods}

Based on the studies that have been done before, urea can be synthesized in several ways. Based on Table 1 the materials, methods, and results of each method will be explained. 
Table 1. Materials, methods and synthesis of urea's results.

\begin{tabular}{|c|c|c|c|c|}
\hline $\begin{array}{c}\text { Raw } \\
\text { Materials }\end{array}$ & Research Group & Method & Reference & Result \\
\hline $\begin{array}{l}\text { Aldehyde with } \\
3 \text { or } 4 \text { atoms of } \\
\text { carbon }\end{array}$ & $\begin{array}{l}\text { Farbwerke Hoechst } \\
\text { Aktiengesellschaft } \\
\text { vormals Meister } \\
\text { Lucius \& Bruining, } \\
\text { Frankfurt am Main, a } \\
\text { corporation of } \\
\text { Germany }\end{array}$ & $\begin{array}{l}\text { Condensation of urea } \\
\text { with aldehydes }\end{array}$ & $\begin{array}{l}\text { S. H. Karl, K. P. } \\
\text { Wilhelm, } 1964^{7} \text {. }\end{array}$ & $\begin{array}{l}\text { The substance } \\
\text { enlarges from } \\
\text { medium to high. } \\
\text { The molecular } \\
\text { weight becomes } \\
5 \% \text { from } 0.2 \% \text { of } \\
\text { the final product. }\end{array}$ \\
\hline $\begin{array}{l}\text { Acrylic Acid } \\
\text { and amylum }\end{array}$ & $\begin{array}{l}\text { Department of } \\
\text { Chemical } \\
\text { Engineering, Faculty } \\
\text { of Engineering, } \\
\text { Universitas } \\
\text { Diponegoro }\end{array}$ & $\begin{array}{c}\text { Fluidized Bed } \\
\text { Spraying Coating } \\
\text { (FBSC) }\end{array}$ & $\begin{array}{l}\text { A. H. Margi, T. } \\
\text { Septiana S. } \\
\text { Triwiningsih, } \\
\text { Suherman, } \\
2012^{8} \text {. }\end{array}$ & $\begin{array}{c}\text { Controlled } \\
\text { Release Urea } \\
\text { (CRU) with a } \\
\text { starch coating has } \\
\text { been successfully } \\
\text { produced by the } \\
\text { FBSC method. }\end{array}$ \\
\hline $\begin{array}{l}\text { Air and natural } \\
\text { gas }\end{array}$ & $\begin{array}{l}\text { Center for Nuclear } \\
\text { Energy Development } \\
\text { (PPEN) - BATAN }\end{array}$ & $\begin{array}{c}\text { The steam reforming } \\
\text { gas process }\end{array}$ & D. H. Salimy, $2012^{9}$. & $\begin{array}{l}\text { Urea fertilizer } \\
\text { from the reaction } \\
\text { of } \mathrm{CO}_{2} \text { and } \\
\text { ammonia. }\end{array}$ \\
\hline $\begin{array}{c}\text { Starch } \\
\text { polymers and } \\
\text { PVA. }\end{array}$ & $\begin{array}{l}\text { Farbwerke Hoechst } \\
\text { Aktiengesellschaft } \\
\text { vormals Meister }\end{array}$ & $\begin{array}{l}\text { Urea coating with } \\
\text { polymers }\end{array}$ & $\begin{array}{l}\text { K. Ivanky, W. R. Tri, } \\
\text { S. Suherman, } 2012^{10} \text {. }\end{array}$ & $\begin{array}{l}\text { Characteristics of } \\
\text { polymer coating } \\
\text { urea can be seen } \\
\text { by the factor of } \\
\text { temperature and } \\
\text { the amount of } \\
\text { starch. }\end{array}$ \\
\hline $\begin{array}{l}\text { Domestic } \\
\text { waste }\end{array}$ & $\begin{array}{l}\text { United State Patent } \\
\text { Application } \\
\text { Publication }\end{array}$ & $\begin{array}{l}\text { Gasification with } \\
\text { temperature selection }\end{array}$ & G. H. Kiss, $2013^{11}$. & $\begin{array}{l}\mathrm{NH}_{3} \text { and } \mathrm{CO}_{2} \text { as } \\
\text { material for } \\
\text { preparation urea. }\end{array}$ \\
\hline Air and water & $\begin{array}{c}\text { Center for the Study } \\
\text { of Nuclear Energy } \\
\text { Systems (PKSEN)- } \\
\text { BATAN }\end{array}$ & $\begin{array}{l}\text { Uses nuclear } \\
\text { cogeneration }\end{array}$ & D. H. Salimy, $2014^{12}$. & $\begin{array}{l}\text { Urea fertilizer } \\
\text { from } \mathrm{CO}_{2} \\
\text { conversion. }\end{array}$ \\
\hline $\begin{array}{l}\text { Chitosan, silica } \\
\text { compound, and } \\
\text { urea }\end{array}$ & $\begin{array}{c}\text { Department of } \\
\text { Chemistry FMIPA } \\
\text { UNESA }\end{array}$ & $\begin{array}{c}\text { Addition of a } \\
\text { chemical compound }\end{array}$ & L. F. E. Wulan, 2017 & $\begin{array}{l}\text { Matrix Chitosan- } \\
\text { silica formed by } \\
\text { producing } \\
\text { fertilizer granules } \\
\text { rose-colored. }\end{array}$ \\
\hline $\begin{array}{l}\text { Fly ash, } \\
\mathrm{NaOH}, \text { and } \\
\text { urea }\end{array}$ & $\begin{array}{c}\text { Department of } \\
\text { Chemical } \\
\text { Engineering, } \\
\text { Politeknik Sriwijaya }\end{array}$ & $\begin{array}{c}\text { Coating method with } \\
\text { Fly Ash Coal and } \\
\mathrm{NaOH}\end{array}$ & $\begin{array}{l}\text { M. Yerizam, I. } \\
\text { Purnamasari, A. } \\
\text { Hasan, } \\
\text { R. Junaidi, } 2017^{14} \text {. }\end{array}$ & $\begin{array}{l}\text { Solid and hard } \\
\text { Slow Release } \\
\text { Fertilizer. }\end{array}$ \\
\hline $\begin{array}{l}\text { Waste cooking } \\
\text { oil, Paraffin, } \\
\text { and urea }\end{array}$ & $\begin{array}{l}\text { Department of } \\
\text { Chemical } \\
\text { Engineering, Faculty } \\
\text { of Engineering, } \\
\text { Universitas Gadjah } \\
\text { Mada Yogyakarta }\end{array}$ & $\begin{array}{c}\text { Urea Fertilizer } \\
\text { Coating Method with } \\
\text { a Mixture of Waste } \\
\text { Cooking Oil and } \\
\text { Paraffin }\end{array}$ & $\begin{array}{c}\text { N. M. Prakarsa, } \\
2012^{15} \text {. }\end{array}$ & $\begin{array}{l}\text { Urea coated with } \\
\text { waste cooking oil } \\
\text { and paraffin. }\end{array}$ \\
\hline
\end{tabular}




\begin{tabular}{|c|c|c|c|c|}
\hline $\begin{array}{l}\text { Urea prill } \\
\text { fertilizer }\end{array}$ & $\begin{array}{c}\text { Department of } \\
\text { Chemistry } \\
\text { Universitas Sumatera } \\
\text { Selatan North }\end{array}$ & Spectrophotometry & $\begin{array}{l}\text { D. I. Muthawali, } \\
2018{ }^{16} \text {. }\end{array}$ & $\begin{array}{l}\text { Urea fertilizer } \\
\text { with different } \\
\text { biuret levels. }\end{array}$ \\
\hline $\begin{array}{l}\text { Chitosan and } \\
\text { Humic Acid }\end{array}$ & $\begin{array}{c}\text { Department of } \\
\text { Chemistry, Faculty } \\
\text { of Mathematics and } \\
\text { Natural Sciences } \\
\text { State Universitas } \\
\text { Surabaya }\end{array}$ & $\begin{array}{l}\text { Slow Release } \\
\text { Fertilizer }\end{array}$ & $\begin{array}{l}\text { P. M. Andika, D. K. } \\
\text { Maharani, } 2018^{17} \text {. }\end{array}$ & $\begin{array}{c}\text { Urea fertilizer } \\
\text { with higher water } \\
\text { absorption. }\end{array}$ \\
\hline $\begin{array}{l}\text { Molecularly } \\
\text { Imprinted } \\
\text { Polymers } \\
\text { (MIPs), } \\
\text { grapefruit from } \\
\text { graphit, and } \\
\text { urea }\end{array}$ & $\begin{array}{l}\text { Department of } \\
\text { Chemistry, } \\
\text { Universitas Sultan } \\
\text { Ageng Tirtayasa }\end{array}$ & $\begin{array}{l}\text { Graphene } \\
\text { preparation }\end{array}$ & I. Irhamni, $2016^{18}$. & $\begin{array}{l}\text { Formation of } \\
\text { urea with } \\
\text { molecularly } \\
\text { imprinted } \\
\text { polymers } \\
\text { (M.I.P.s). }\end{array}$ \\
\hline $\begin{array}{l}\text { Urea, } \\
\text { glutaraldehyde, } \\
\text { chitosan, } \\
\text { organic } \\
\text { compound } \\
\text { solvent }\end{array}$ & $\begin{array}{l}\text { Department of } \\
\text { Chemical } \\
\text { Engineering, Faculty } \\
\text { of Engineering, } \\
\text { Universitas Sultan } \\
\text { Ageng Tirtayasa }\end{array}$ & Cross-linking & $\begin{array}{l}\text { R. S. D. Lestari, } \\
2020^{19} \text {. }\end{array}$ & $\begin{array}{l}\text { Microsphere } \\
\text { chitosan. }\end{array}$ \\
\hline $\begin{array}{l}\text { Sulfur, Starch, } \\
\text { PVA, POP, } \\
\text { Molasses, } \\
\text { Gelatin, and } \\
\text { Paraffin Wax }\end{array}$ & $\begin{array}{c}\text { Department of } \\
\text { Chemical } \\
\text { Engineering, } \\
\text { Department of } \\
\text { Agronomy, Research } \\
\text { and Development } \\
\text { Departement, and } \\
\text { Department of } \\
\text { Evirontmental } \\
\text { Sciences, Pakistan }\end{array}$ & $\begin{array}{c}\text { Coating Use Organic } \\
\text { and Inorganic }\end{array}$ & $\begin{array}{c}\text { B. Beig, M. B. Niazi, } \\
\text { Z. Jahan, E. } \\
\text { Pervaiz, } \\
\text { G. Abbas Shah, M. } \\
\text { Ul Haq, M. I } \\
\text { Zafar, } \\
\text { M. Zia, 2020 }\end{array}$ & $\begin{array}{c}\text { Coating of urea } \\
\text { prills C-1 } \\
\text { improved N } \\
\text { release pattern } \\
\text { with an } \\
\text { efficiency of } \\
6.87 \% \text {, which } \\
\text { was four times } \\
\text { higher than other } \\
\text { coated } \\
\text { fertilizers. }\end{array}$ \\
\hline
\end{tabular}

\subsection{Urea Condensation Method with Aldehyde and Result}

The researchers found that the aldehyde condensation method is challenging because it usually produces much dust in high enough quantities.

The process of preparation granular fertilizer by condensing urea with an aldehyde contains 3-4 carbon atoms. Substances are added to the starting product before condensation to increase the molecular weight, such as modified cellulose, methylcellulose or carboxymethyl cellulose. Modified polyacrylonitrile, like polyacrylamide, polyvinyl alcohol, or substances of medium to high molecular weight, having similar properties in the amount range, 0.2 to $5 \%$, especially 0.3 to $1 \%$, is calculated on the final product ${ }^{7}$.

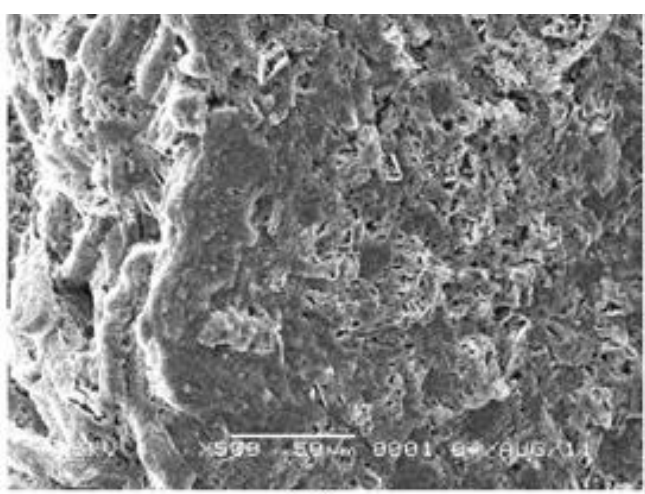

(a)

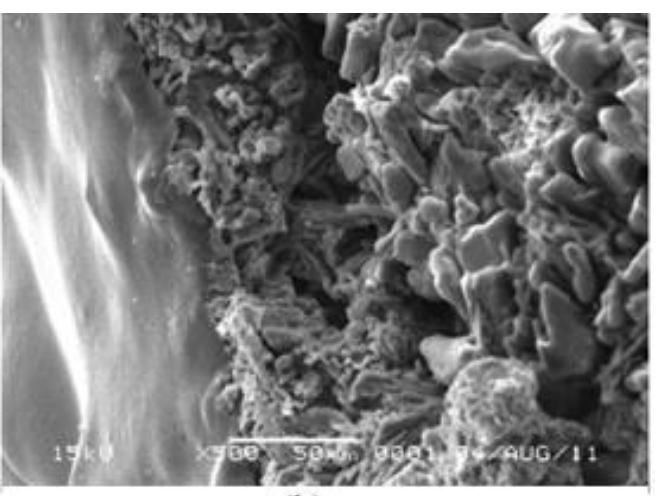

(b)

Figure 1. The result of urea with coating without coating (a) and (b) with coating Figure taken from Margie Agami Haq (2012) ${ }^{8}$ 
Two results were obtained with different concentrations. In experiment one, $92 \%$ of the granules of the product had a particle size of 0.2 to 3 $\mathrm{mm}$. The product also contains $32.2 \%$ nitrogen, including $45 \%$ soluble in water, $54 \%$ difficult to dissolve in water, and $1 \%$ insoluble in water. The second experiment produces a urea product with finegrained and does not create dust. Nitrogen in the second experimental product is $30 \%$ with $33 \%$ soluble in water, $66 \%$ is difficult to dissolve in water, and $1 \%$ is insoluble ${ }^{7}$.

\subsection{Fluidized Bed Spraying Coating (FBSC) Methods and Results}

Figure 1 is obtained from the SEM test results. Figure 1 (a) shows that urea only consists of one layer, but in Figure 1 (b), it can be seen that there are two layers, consist of urea and coating. The purpose of
SEM testing is to determine the microscopic image of the product surface obtained. The coating spread equally on the surface of urea expected in the process. Observation of the appearance and shape of the surface was carried out before and after coating. The image is shot at 500x magnification ${ }^{8}$.

Controlled Release Urea (CRU) with a starch coating has been successfully produced by the FBSC method. The greater the bed temperature used, the dissolution rate will increase. However, the speed of the dissolution rate will decrease as the starch concentration increases. A dustiness will increase with elevating bed temperature and the concentration of starch used. The coating efficiency decreases with an increase in bed temperature and vice versa ${ }^{8}$.

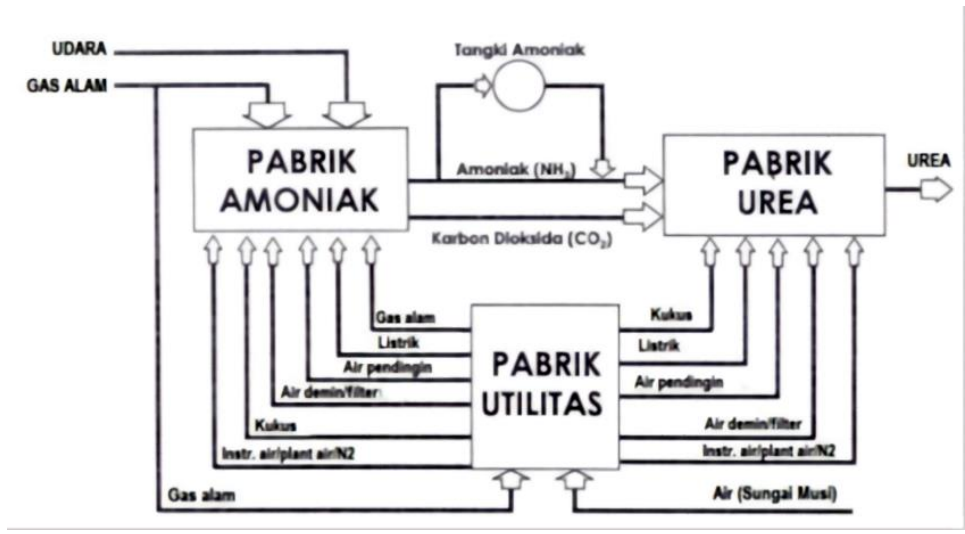

Figure 2. Block Diagram of Urea Fertilizer Manufacturing. Figure taken from PT. Pupuk Sriwijaya (2011) ${ }^{21}$

\subsection{Steam Reforming Gas Method}

Based on Figure 2 about block diagram of urea fertilizer manufacturing, the preparation of urea fertilizer on a factory scale can be started by mixing natural gas and air into the ammonia factory, processing it, and the results further processed with the urea factory.

The ammonia plant unit serves to produce ammonia and the reverse process that requires the most energy. In the conventional method, natural gas raw materials are used with steam reforming process at high temperatures $\left(\sim 800^{\circ} \mathrm{C}\right)$ to produce synthesis gas (a mixture of $\mathrm{H}_{2}$ and $\mathrm{CO}_{2}$ ) as follows ${ }^{22}$ :

$$
\begin{aligned}
& \mathrm{CH}_{4}+\mathrm{H}_{2} \mathrm{O} \rightleftharpoons 3 \mathrm{H}_{2}+\mathrm{CO} \ldots \\
& \mathrm{CH}_{4}+2 \mathrm{H}_{2} \mathrm{O} \rightleftharpoons 4 \mathrm{H}_{2}+\mathrm{CO}_{2} \\
& \mathrm{CO}+\mathrm{H}_{2} \mathrm{O} \rightleftharpoons \mathrm{H}_{2}+\mathrm{CO}_{2} \ldots
\end{aligned}
$$

Furthermore, the $\mathrm{CO}$ formed in reaction (1) is rereacted with water to form the $\mathrm{CO}_{2}$ needed to produce urea.

$\mathrm{CO}+\mathrm{H}_{2} \mathrm{O} \rightleftharpoons \mathrm{CO}_{2}+\mathrm{H}_{2}$
The hydrogen produced in reactions (1) and (2), is reacted with nitrogen from the air to form ammonia gas following the reaction equation:

$\mathrm{N}_{2}+3 \mathrm{H}_{2} \rightleftharpoons 2 \mathrm{NH}_{3}$

In the urea plant unit, ammonia is reacted with $\mathrm{CO}_{2}$ obtained at the ammonia plant unit, which through a two-step reaction is produced urea.

$2 \mathrm{NH}_{3}+\mathrm{CO}_{2} \rightleftharpoons \mathrm{NH}_{2} \mathrm{COONH}_{4}$ (ammonium carbamate).

$\mathrm{NH}_{2} \mathrm{COONH}_{4} \rightleftharpoons \mathrm{H}_{2} \mathrm{O}+\mathrm{NH}_{2} \mathrm{CONH}_{2}$ (urea)

In the production of urea, the emission levels of $\mathrm{CO}_{2}$ obtained from natural gas use as fuel. The utilization of a high-temperature nuclear reactor can meet all the factory's thermal energy so that natural gas is only needed as a raw material.

Reaction:

$\mathrm{CH}_{4}+2 \mathrm{O}_{2} \rightarrow \mathrm{CO}_{2}+2 \mathrm{H}_{2} \mathrm{O}$

Molecular weight of $\mathrm{CH}_{4}=16$ and molecular weight of $\mathrm{CO}_{2}=44$.

Natural gas of $12,307,057.75$ MMBTU per year is equivalent to $261162331.65 \mathrm{~kg} /$ year. So that the 
potential for reducing $\mathrm{CO}_{2}$ emissions is $=44 / 16 \mathrm{x}$ $261162331.65=718,196.42$ tons/year.

It can be seen from the calculation results that the application of high-temperature nuclear reactor heat energy can save the depletion of natural gas fossil energy resources, which directly impacts the potential to reduce the rate of greenhouse gas emissions ${ }^{12}$.

\subsection{Method of coating urea fertilizer with polymer (starch and PVA) and result}

Recently, researchers have increased their efforts to use polymers in combination with starch as a coating material. Starch is a polysaccharide polymer that is available in vast quantities. Starch is blended with synthetic polyvinyl alcohol (PVA) polymer as a biodegradable polymer ${ }^{23}$.
According to the research, urea is served with a starch polymer from tapioca flour and polyvinyl alcohol (PVA) by spraying it on a fluid mount. The variables discussed were temperature and starch amount on coating efficiency, dissolution rate, and dust. The research was conducted by filtering the urea with a shaker and then serving it every $100 \mathrm{~g}^{10}$.

The results of coating urea with starch can be seen by Scanning Electron Microscopy (SEM). In Figure 3. (a) pure urea enlargement before the coating is carried out up to $500 \mathrm{x}$, and it can be seen that there is more cavity or free space. Meanwhile, in Figure 3. (b), polymer-coated urea looks solid and not hollow when the urea has been coated with starch and PVA ${ }^{10}$.
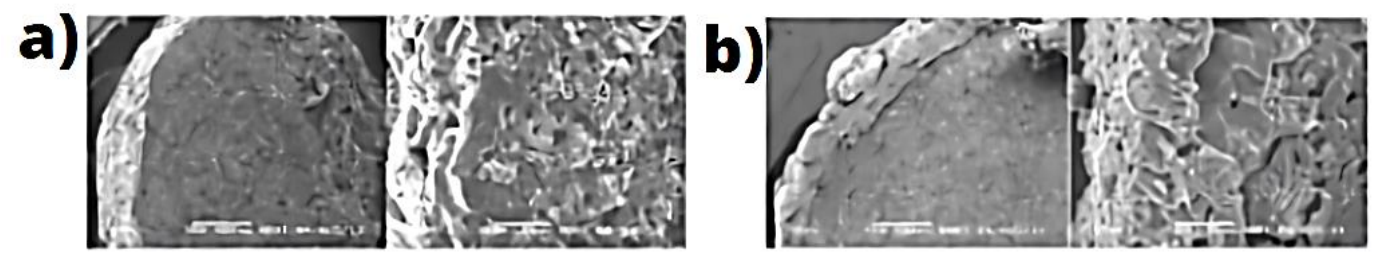

Figure 3. Cross-sectional Urea (a) Pure and (b) Polymer Coated. S.E.M. analysis of cross-sectional urea in 50x and 500x magnifications. Figure taken from Ivanky, K. Tri, WR. (2012) ${ }^{10}$

\subsection{Thermoselect Method}

All the process used for the synthesis of ammonia is development with Haberbosch process in Germany. This process involves hydrogen and nitrogen reaction under high temperature and pressure with an iron catalyst based and requires great energy ${ }^{24}$.

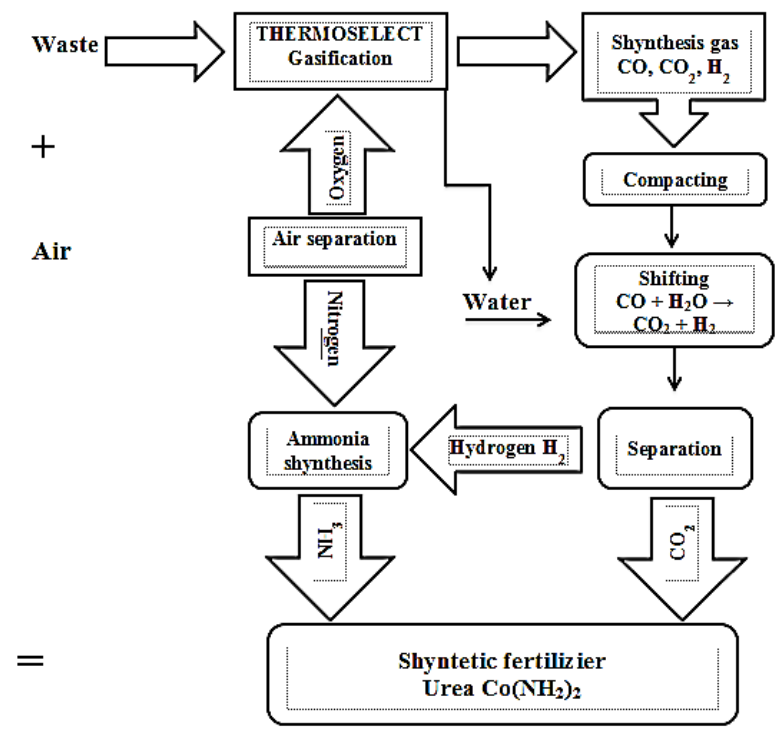

Figure 4. Scheme Steps Preparation of Thermoselect Method. Scheme taken from Locarno (2013) ${ }^{11}$

According to Figure 4 about scheme steps preparation of thermoselect method, the experiment was done by Locarno (2013). The first step is $\mathrm{CO}_{2}, \mathrm{CO}$, and $\mathrm{H}_{2}$ gas synthesis of gasification in high temperature as a byproduct of pure use oxygen selection temperature. Therefore, $\mathrm{CO}$ contained in a gas will be changed to $\mathrm{CO}_{2}$ and $\mathrm{H}_{2}$ in $\mathrm{H}_{2} \mathrm{O}$ vapor. Then, $\mathrm{H}_{2}$ gas formed from
$\mathrm{CO}_{2}$ and $\mathrm{H}_{2}$ converted into $\mathrm{NH}_{3}$ and $\mathrm{N}_{2}$ as a byproduct. The final result of this method is $\mathrm{NH}_{3}$ and $\mathrm{CO}_{2}$ as material for preparation urea. The benefit of this method is not producing gas emissions. All substances formed can be used, so this is a low-cost process needed ${ }^{11}$. 


\subsection{Nuclear Cogeneration Method}

Nuclear cogeneration is a method that can be used in the manufacture of urea fertilizer. Nuclear cogeneration has the advantage of saving natural gas reserves. Besides that, it will also have implications for reducing the rate of $\mathrm{CO}_{2}$ emissions to be more environmentally friendly and reduce the impact of global warming due to emissions from $\mathrm{CO}_{2}{ }^{12}$.
Based on Figure 5 about flow charts of the nuclear urea fertilizer production process, nuclear cogeneration for water decomposition is the thermochemical process of breaking down water molecules into hydrogen and oxygen by utilizing nuclear thermal energy to carry out the process. This process is an important candidate for hightemperature nuclear reactor applications for producing hydrogen from water.

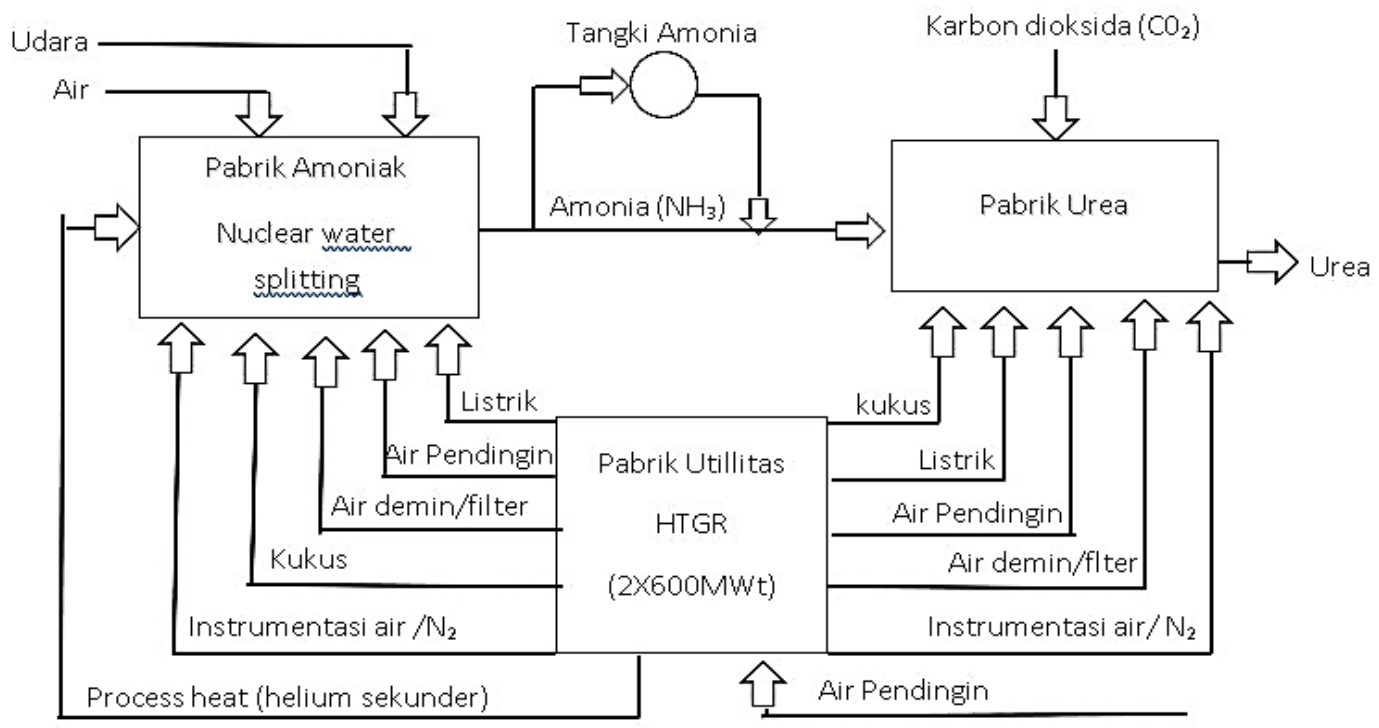

Figure 5. Flow Chart of Nuclear Urea Fertilizer Production Process. Figure taken from Salimy, Djati H. (2012) ${ }^{9}$

The main units in a urea fertilizer plant include an ammonia factory, urea factory, and utility factory. In the ammonia plant, by utilizing nuclear cogeneration technology for water decomposition, the process that is replaced forms hydrogen in the ammonia plant unit process. The reaction of hydrogen formation by the thermochemistry process of the iodine-sulfur cycle with nuclear heat is used to replace the natural gas steam reforming process. The reaction for the formation of hydrogen is as follows:

$$
\begin{aligned}
& \mathrm{SO}_{2}+\mathrm{I}_{2}+2 \mathrm{H}_{2} \mathrm{O} \rightleftharpoons \mathrm{H}_{2} \mathrm{SO}_{4}+2 \mathrm{HI} \ldots \ldots \\
& \mathrm{H}_{2} \mathrm{SO}_{4} \rightleftharpoons \mathrm{SO}_{2}+\mathrm{H}_{2} \mathrm{O}+1 / 2 \mathrm{O}_{2} \ldots \ldots . \\
& 2 \mathrm{HI} \rightleftharpoons \mathrm{I}_{2}+\mathrm{H}_{2} \ldots \ldots \ldots \ldots \ldots \ldots \ldots \ldots \ldots \ldots \ldots \ldots \ldots
\end{aligned}
$$

In contrast to the natural gas steam reforming reaction that produces $\mathrm{CO}_{2}$, this reaction does not produce $\mathrm{CO}_{2}$ needed in the urea plant unit's urea formation process. Because of that, $\mathrm{CO}_{2}$ must be supplied from outside the system. The reactions that occur in the urea plant units are the same as those in conventional processes, and only the source of $\mathrm{CO}_{2}$ is different. In the traditional method, $\mathrm{CO}_{2}$ is obtained from the steam reforming reaction of natural gas, while in nuclear cogeneration applications, $\mathrm{CO}_{2}$ is obtained from outside the system ${ }^{12}$.

$2 \mathrm{NH}_{3}+\mathrm{CO}_{2} \rightleftharpoons \mathrm{NH}_{2} \mathrm{COONH}_{4}$ (ammonium carbamate).

$\mathrm{NH}_{2} \mathrm{COONH}_{4} \rightleftharpoons \mathrm{H}_{2} \mathrm{O}+\mathrm{NH}_{2} \mathrm{CONH}_{2}$ (urea)

High-temperature atomic reactors constitute a significant component of utility plants. The needs of all types of energy (heat, steam, and electricity) are fully supplied using high-temperature nuclear reactors. Process heat energy is met by utilizing secondary helium to carry out the nuclear cogeneration process. Simultaneously, steam and electricity requirements are obtained by converting some of the secondary helium's heat energy into steam and electricity ${ }^{12}$.

\subsection{Slow Release With Matrix Chitosan-Silica Method and Result}

Chitosan is composed of poly (2-deoxy-2acetylamino-2-glucose) and poly (2-deoxy- 2-amino glucose) that binds (1-4) $\beta$-glycosidic. Characteristics of chitosan are non-toxic, biodegradable and biocompatible ${ }^{25}$. 


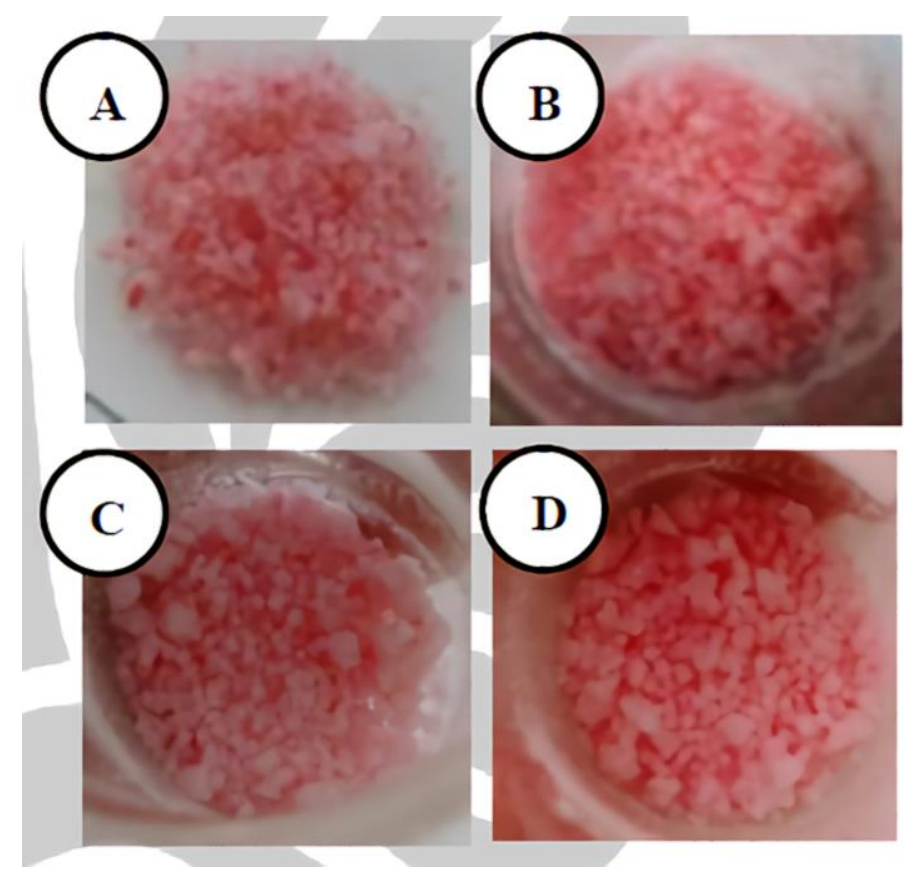

Figure 6. The Result of Slow Release with Matrix Chitosan-Silica Process Produce Matrix. Chitosansilica formed by producing fertilizer granules rose-colored. Figure taken from Wulan and Maharani $(2017)^{13}$

Preparation of $0.2 \%$ chitosan solution is formed by dissolving $0.2 \mathrm{~g}$ of chitosan in $100 \mathrm{~mL}$ of $2 \%$ acetic acid solution. The silica sol made from TEOS precursor and $\mathrm{HCl}$ catalyst is hydrolyzed in ethanol for 24 hours. Furthermore, preparation of chitosansilica matrix by stirring a mixture of chitosan solution and silica sol with various compositions. After all the materials are ready, matrix chitosan-silica mixed with urea fertilizers and stored for 4-5 days in a desiccator. The release of nitrogen testing uses a process spectrophotometer to prove release levels according to the ISO standard. Four times the release of nitrogen testing showed in Figure 6 that matrix chitosan and silica by comparison 1.5: 1.5 is about the release less than $15 \%$ and the release of nutrients for 28 days almost $75 \%$. Fertilizer slow release with matrix chitosan-silica formed by producing fertilizer granules rose-colored ${ }^{13}$.

\subsection{Coating method with Fly Ash Coal and $\mathrm{NaOH}$ and Result}

Fly ash and $\mathrm{NaOH}$ are mixed with a specific ratio (in $\%$ volume) then stirred evenly. The urea that has been sifted in a certain amount (ratio based on volume\% to FA) is stirred into the FA- $\mathrm{NaOH}$ mixture. Then the FA-NaOH urea was formed into pellets. The product is soluble in water, and the duration of release in the soil was observed ${ }^{14}$.

Based on research conducted by Yerizam, Muhammad et al. (2017), modified urea is quite wellformed without heating during mixing. At the time of preparation, modified urea by heating it produces modified urea, which is very dilute because $\mathrm{NaOH}$ and urea are hygroscopic. So, modified urea is made without heating, and the product is produced in Figure $7^{14}$.

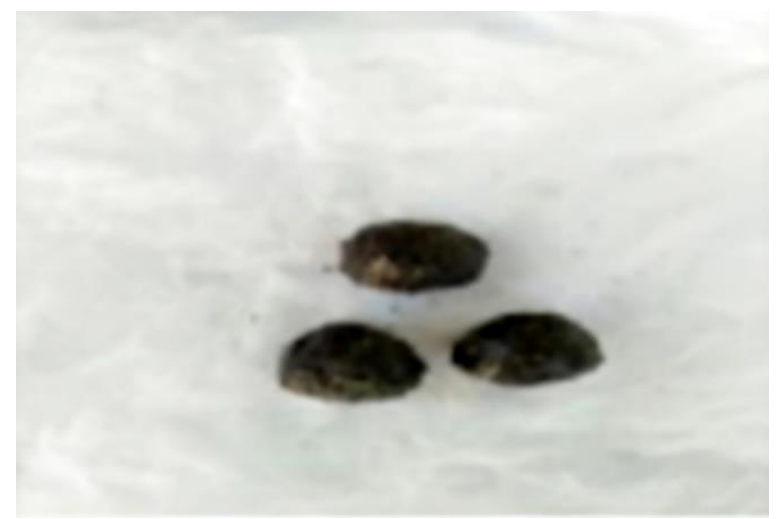

Figure 7. Modification Results on Products. Modified urea, the result of fly ash and NaOH method. Figure taken from Yerizam, Muhammad et al. (2017) ${ }^{14}$ 
The solubility results of modified urea (based on Table 2) were compared with urea prills in water with the same weight; the following results are obtained. Based on Table 2 about long-time urea and modified urea dissolved in water are different. Urea dissolved in water with 1 minute 10 seconds faster than modified urea. Because modified urea contains more components than urea, modified urea is slower dissolved in water than urea.

Table 2. Solubility Of Urea and Modified Urea in Water. Figure taken from Yerizam, Muhammad et al. $(2017)^{14}$.

\begin{tabular}{|c|c|}
\hline Component & Long-Time Dissolved in water \\
\hline Urea & 15 minutes 10 seconds \\
\hline Modified Urea & 16 minutes 20 seconds \\
\hline
\end{tabular}

The test results on the soil release time consisting of different ratios are shown in Figure 8. five samples of urea prills and modified urea with

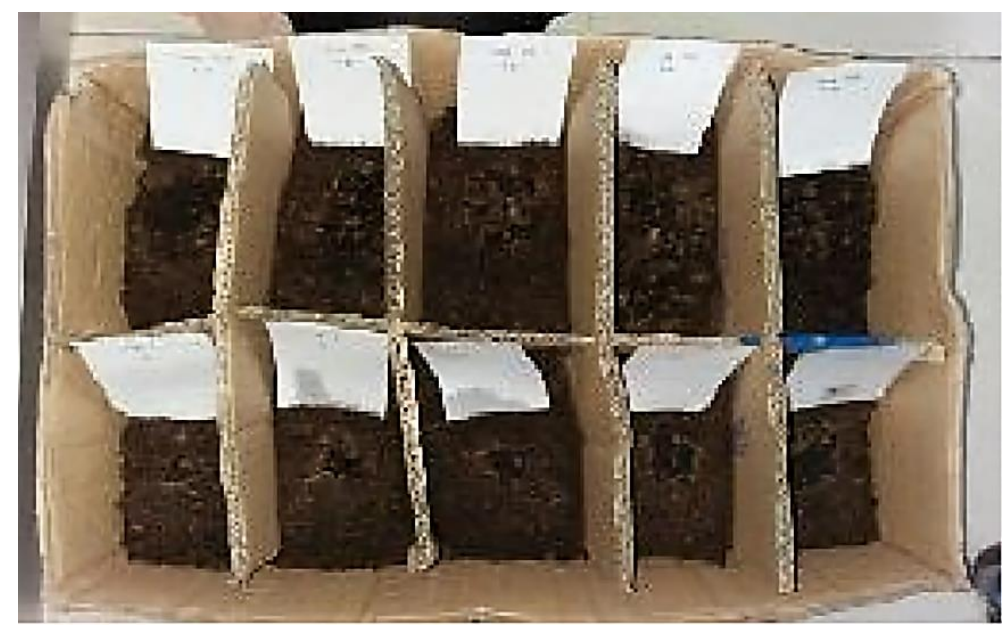

Figure 8. Product Testing Results. The product in 12 hours after tested. Figure taken from Yerizam, Muhammad et al. (2017) ${ }^{14}$

Based on the results, urea prills quickly release nitrogen more than modified urea. The relationship between time release and the amount of urea released in the soil is illustrated in Figure 9.

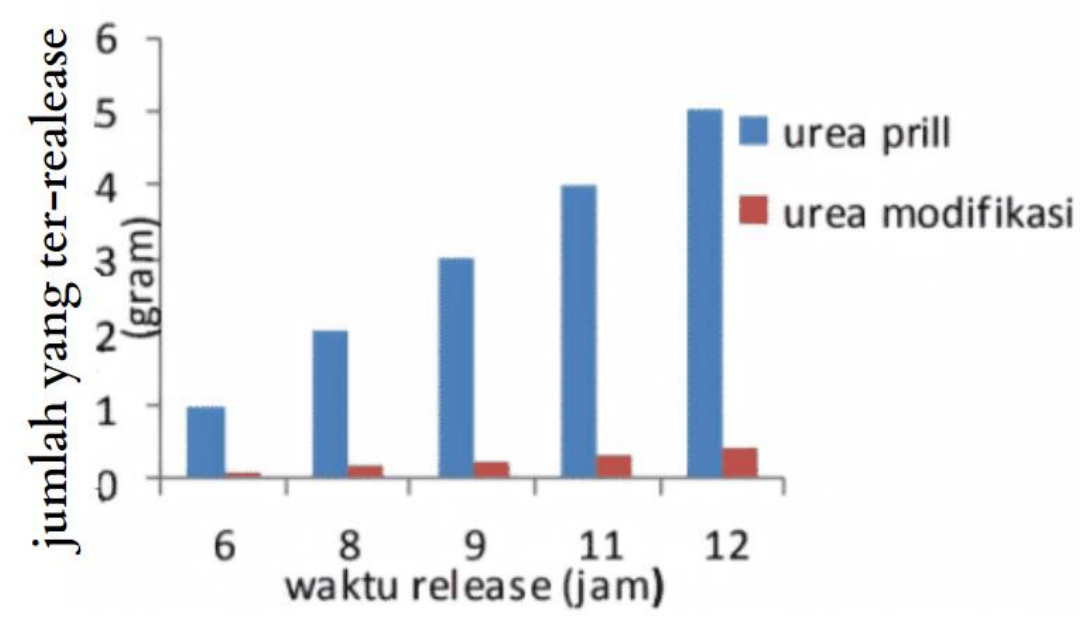

Figure 9. Effect of Release Time Graphic. The graphic shows in hours the number of releases. Figure taken from Yerizam, Muhammad et al. (2017) ${ }^{14}$

Figure 9 about the effect of release time graphic between modified urea and urea prill indicates that the modified urea product is good enough to be used as a slow-release fertilizer. The resulting product is quite dense and hard compared to ordinary urea prills so that it does not dissolve quickly from standard urea ${ }^{14}$. 


\subsection{Urea Fertilizer Coating Method with a Mixture of Waste Cooking Oil and Paraffin and Result}

Materials and tools needed for this method are urea prills, urea analytic with $99 \%$ purity, solid paraffin, and used cooking oil. This research using SpectroVis Plus Spectrophotometer.

Then dried at $100^{\circ} \mathrm{C}$ in an oven for 1 day and stored in a desiccator. Then prepare a beaker containing a mixture of $7 \mathrm{~g}$ of paraffin and used cooking oil. Place it on a hot plate at $70^{\circ} \mathrm{C}$. When the paraffin mixture melts, then add the urea fertilizer gradually, then stir it so that the urea and paraffin mixture is evenly distributed. The resulting mixture was dried in a desiccator for 48 hours. The initial analysis used is to calculate the sample coating efficiency using the following equation ${ }^{15}$.

$$
\eta=\frac{(m f-m o)}{\operatorname{mo} \times 100 \%}
$$

The first step to determine the amount of nitrogen released is to make a standard solution using distilled water. The solution was analyzed using a U.V./Vis spectrophotometer by looking for the maximum absorbance value produced; these results were used to determine the maximum wavelength $(\lambda \max )$ to be used in the urea coating sample test. The test sample was carried out using $25 \mathrm{~g}$ of sample urea coating, put in $250 \mathrm{~mL}$ of distilled water, and placed at room temperature. The amount of urea must match the urea concentration in the range of the calibration curve. Samples were allowed to stand for a variety of 2-5 days. The amount of nitrogen released was calculated from the urea concentration until nitrogen release reached $99 \%$. This analysis was repeated 3 times to get accurate results ${ }^{15}$.

The manufacture of slow-release fertilizer (SRF) using a coating of $7 \mathrm{~g}$ of used cooking oil and paraffin on urea produce in a coating efficiency of $6.6 \%$, while the UV/VIS analysis results using a standard solution in the Vernier SpectroVis Plus Spectrophotometer to find the maximum wavelength value at $424 \mathrm{~nm}$. Whereas in the test for decreasing nitrogen concentration at various times (days), the maximum nitrogen release time was obtained on the 3rd day with a nitrogen release concentration of $33100 \mathrm{ppm}^{15}$.

\subsection{Spectrophotometric Methods and Result}

Spectrophotometry is an analytical method based on measuring monochromatic light absorption by a strip of colored solutions at a specific wavelength using a prism monochromator or diffraction grating with a phototube detector ${ }^{26}$.

Spectrophotometry is used to analyze the concentration of a substance in a solution based on the absorbance of the solution's color at a particular wavelength. Simultaneously, the spectrophotometer is a tool for measuring the transmittance or absorbance of a sample as a wavelength function. In addition, a spectrophotometer can also use a bottomup technique. The bottom-up process is a synthesis technique with a high enough particle homogeneity. To find out the results of urea-hydroxyapatite synthesis, it is necessary to perform Scanning Electron Microscopy (SEM) characterization to observe particle morphology, Energy Dispersive XRay Spectrometry (EDX) to observe elemental composition, Fourier Transform Infrared Spectrometer (FTIR) to observe the bonds between elements, and Particle Size Analyzer (PSA) to observe particle size distribution ${ }^{27}$.

Based on the urea prill as a sample from PT PUSRI analysis result, the biuret content in urea prill on average is $0.31 \%$. Meanwhile, the urea prill fertilizer at PT PIM, the urea prill's biuret content on average, is $0.34 \%$. The two fertilizers that have been studied show that the value of biuret content in good quality urea is in accordance with the value set by the Indonesian National Standard (SNI) 02-2801$1998^{16}$.

\subsection{SFR (Slow-release Fertilizer) Method with Chitosan - Humate Acid Matrix}

The main principle of SRF fertilizer is to create a barrier in molecular interactions so that the nutrients in the fertilizer do not easily escape into the environment ${ }^{28}$.

To prepare chitosan-humate acid slow-release fertilizer, it is necessary to prepare urea fertilizer for the grinding and sieving process with a 60 mesh sieve. Furthermore, the urea fertilizer produced by the sieve was mixed with Chitosan-humate acid composites with various concentrations and stirred using a magnetic stirrer for 2 hours. Moreover, the samples were dried in an oven at $60^{\circ} \mathrm{C}{ }^{17}$.

Testing of water absorption (swelling) can be done by weighing $0.5 \mathrm{~g}$ of the fertilizer sample placed on filter paper, where the filter paper is measured first. Furthermore, $2 \mathrm{~mL}$ of Aqua DM was added and left 24 hours at $25^{\circ} \mathrm{C}$ (room temperature). Then the measuring process and the calculation of the swelling power are carried out, which are as follows:

$$
\% \text { Swelling Power }=\frac{M-M o}{M o} \times 100 \%
$$

Description :

$\mathrm{M}=$ sample that has undergone splitting

Mo $=$ dry samples that have not yet undergone refinement ${ }^{17}$. 


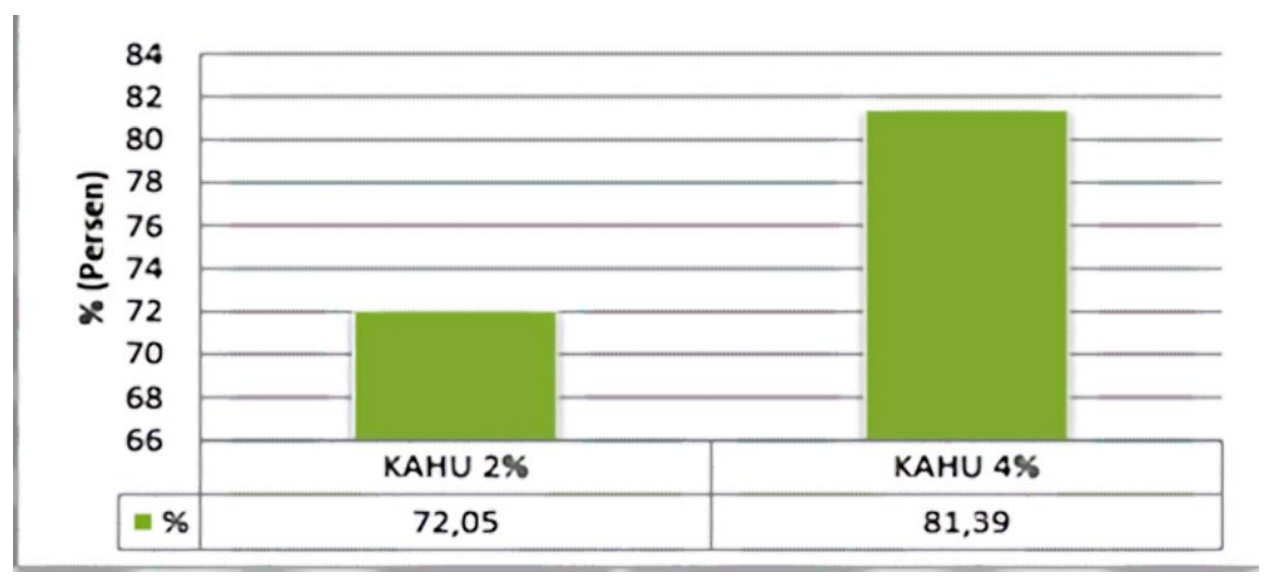

Figure 10. Graph of Fertilizer Swelling Power. The swelling power of the fertilizer is calculated over 24 hours. Figure taken from Andika, PMV. and Maharani, DK. (2018) ${ }^{17}$

Based on Figure 10 about percent of the swelling test, it was found that the effect of humate acid in the fertilizer sample was quite large, so that the higher the concentration of the Chitosan-humate acid matrix, the greater the percentage of water absorption (swelling) in the fertilizer sample which can be seen in Figure 10 . With the nature of humate acid like a sponge with a large surface area and a linear molecular structure when interacting with chitosan, it can absorb and hold large amounts of water ${ }^{17}$. (Andika, P.M.V. And Maharani, KD. 2018)

\subsection{Graphene Preparation Method and Result}

Grapefruit preparation is a MIPs adsorption mechanism against urea which occurs through hydrogen bonds in the mold pores of MIPs compounds ${ }^{29}$.

The urea research began with the preparation of grapefruit from graphite. Molecularly Imprinted Polymers (MIPs) compound preparation to determine the optimal preparation conditions, chemical characterization, and surface morphology using IR, $\mathrm{XRD}$, and SEM ; then proceed with the characterization of the MIPs compound adsorption on urea. Research on Molecularly Imprinted Polymers (MIPs) has experienced significant development, especially about its use as an adsorbent because of its high sensitivity and selectivity. Apart from that, its preparation is easy and cheap. Molecularly Imprinted Polymers (MIPs) have been successfully prepared using chitosan which is composited with graphene as the polymer, and urea as the template compound. The MIPs compound formed can be used as an adsorbent on urea. The adsorption ability of MIPs to urea gradually increased in proportion to the increase in concentration and interaction time with the analyte ${ }^{18}$.

\subsection{Cross-linking method and result}

Based on research, microsphere chitosan containing urea fertilizer and cross-linking with glutaraldehyde. Changes in the concentration of a chitosan and glutaraldehyde solution can affect characterization microsphere chitosan filled fertilizer urea as particles' size. A change in temperature relating to the melting point, and identification in the crystalline phase, this study aims to determine characterization microsphere chitosan who cross-linked by glutaraldehyde as a matrix to the release of under control (a controlled release) urea fertilizer ${ }^{19}$.
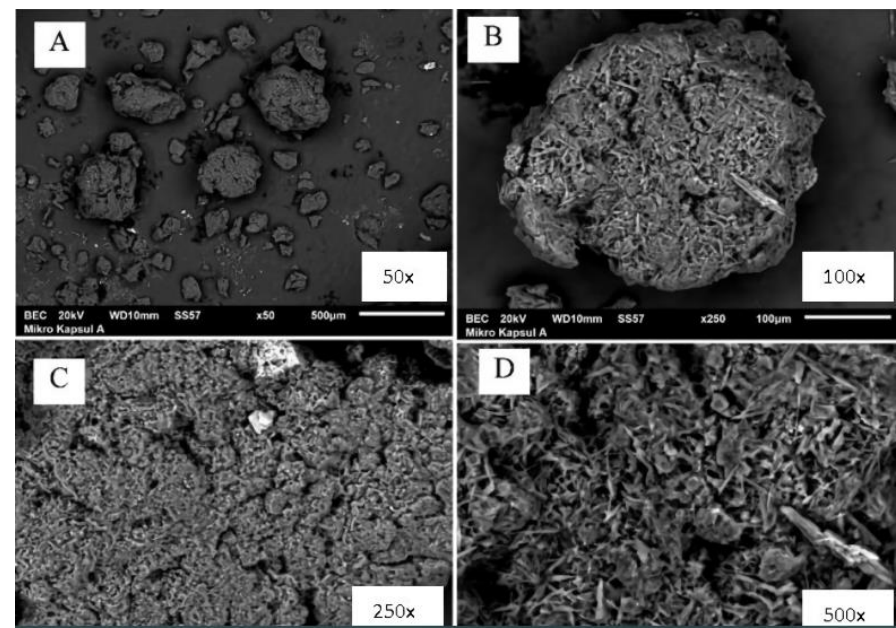

Figure 11. The Result of Cross-Linking Method with Glutaraldehyde. Morphological analysis of urea fertilizer microcapsules with magnification of (A) $50 \mathrm{X}$, (B) 100x, (C) $250 \mathrm{X}$, and(D) 500X. Figure taken from Lestari, RSD, et al. (2020) ${ }^{19}$ 
The research materials used were urea, glutaraldehyde solution, toluene, chitosan, vegetable oil, glacial acetic acid, petroleum ether, $n$-hexane. All ingredients are mixed one by one and stirred for 2 hours until microsphere chitosan is formed. Then the microsphere chitosan that is created will be filtered, washed, and dried using an oven; the next stage of the microsphere chitosan will be characterized to determine the particle size, melting point, and shape of the crystalline phase.

Based on Figure 11, the result morphological analysis urea microcapsules have already formed with the surface coarse and aggregates shape.

Based on the urea microcapsule release results, the higher the concentration of glutaraldehyde and chitosan, the lower the urea fertilizer's cumulative release. Glutaraldehyde, as a cross-linking agent function, binds the amine groups of chitosan. The presence of these bonds causes an increase in viscosity and causes the chitosan matrix's hydrophobic properties to increase, and causes a decrease in the mobility of the macromolecular chains ${ }^{30}$.

\subsection{Coating Use Organic and Inorganic Method and Result}

For the synthesis of spray coating solutions, $10 \mathrm{~g}$ of starch was mixed with $100 \mathrm{~mL}$ of deionized water at a constant temperature of $80^{\circ} \mathrm{C}$ for $30 \mathrm{~min}$. Then, purposed quantities of polyvinyl alcohol, sulfur, and Paraffin wax were added to the starch-based deionized water solution while maintaining the solution temperature at $80^{\circ} \mathrm{C}$. Thus, the final solution was ready for its application as a coating material over urea prills. Due to the smaller particle size, the handling of urea prills was complicated during the coating process. A similar methodology was adopted to synthesize all fertilizer formulations, as mentioned in Table $3^{20}$.
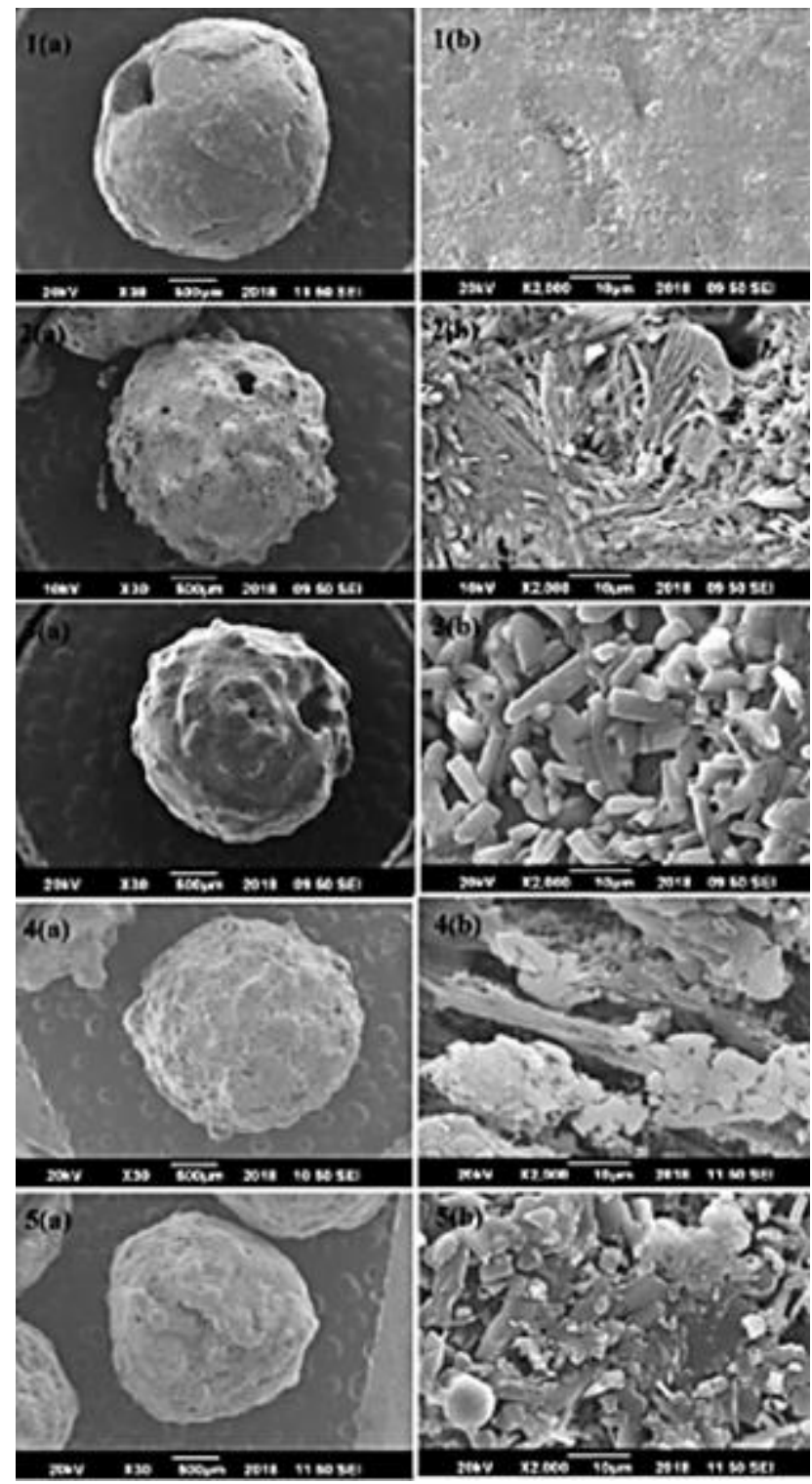

Figure 12. SEM Micrographs of Uncoated and Coated Urea. (1: uncoated urea, 2: C-1 coated, 3: C-2 coated, 4: C-3 and 5: C-4 coated) ( $\mathrm{a}=$ at 30 magnification and $\mathrm{b}=$ at 2000). Figure taken from Beig, B. et al. (2020) ${ }^{20}$ 
Table 3. Composition of Coating solutions used in the study.

\begin{tabular}{|c|c|c|c|c|c|c|c|}
\hline \multirow{2}{*}{$\begin{array}{c}\text { Treatment } \\
\text { Code }\end{array}$} & Sulfur & Starch & PVA $*$ & POP ** & Molasses & Gelatin & $\begin{array}{c}\text { Paraffin } \\
\text { Wax }\end{array}$ \\
\cline { 2 - 8 } & & \multicolumn{7}{|c|}{$\left(\mathbf{g}(\mathbf{1 0 0} \text { g of urea })^{-\mathbf{1}}\right)$} \\
\hline C-1 & 5 & - & 5 & 10 & - & - & 2 \\
\hline C-2 & 5 & 10 & 5 & - & - & - & 2 \\
\hline C-3 & 5 & - & - & 10 & - & 5 & 2 \\
\hline C-4 & 5 & 10 & 5 & - & 2.5 & - & 2.5 \\
\hline
\end{tabular}

* PVA = Poly Vinyl Alcohol, ** POP = Plaster of Paris

Based on Figure 12, the uncoated urea's surface in Figure 12 (b1) looked softer, but the surface has some spot on it. After urea was coated, which was found in Figure (b2, b3, b4, and b5), the surface looked rougher, but the spot was covered with some materials used for spray coating solutions. The surface on each different material used for coating shows that the difference of each urea coated. The surface can be rougher, or it seems that the surface has some spots too. But if only by SEM analysis, it will not be enough to know which one of 4 coated urea is more efficient. To be more specific, which coated urea is more efficient for slow-release urea can be shown in Figure 13.
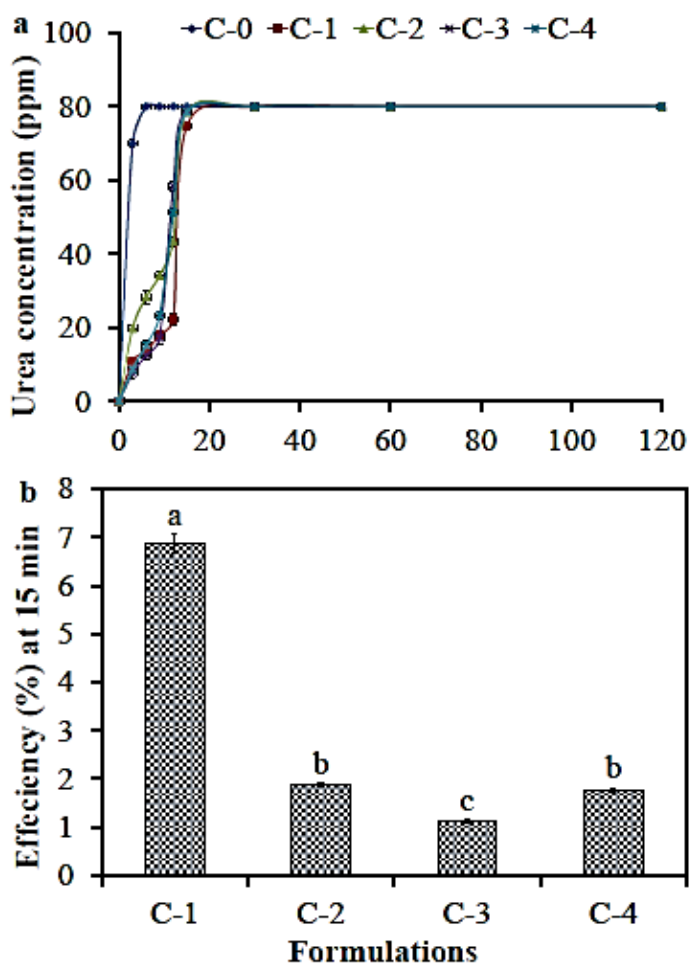

Figure 13. Effect and Efficiency Of Coated Urea. (a) Effect of coating on release rate and (b) efficiency of coated urea formulations. Error bars represent the standard error of the means. Different small letters above bars show significant differences among treatments at $5 \%$ probability level. Figure taken from Beig, B. et al. ${ }^{20}$

Based on Figure 13, POP, PVA, and sulfur combinations with Paraffin wax (C-1) depicted an efficiency of $6.87 \%$. POP's binding ability with wax was stronger and compatible, ultimately resulting in a reliable coating, as shown in SEM Figure 12 (a2,b2). The SEM micrograph of C-3 coated urea also supported this release, probably because of insufficient coating, which looked like a fibrous rodlike structure formed because of POP and para_n wax, which possessed poor compatibility against each other. The samples composed of POP depicted better efficiency than different formulations, probably due to the sparingly soluble property of POP ${ }^{20}$.

All those methods of synthesis of urea must have strengths and weaknesses. There are some weaknesses and strengths that are already discussed and mentioned in Table 4. 
Table 4. Weaknesses and Strengths of Each Method.

\begin{tabular}{|c|c|c|c|c|c|}
\hline Raw Material & $\begin{array}{l}\text { Research } \\
\text { Group }\end{array}$ & Reference & Method & Weaknesses & Strengths \\
\hline $\begin{array}{l}\text { Aldehydes } \\
\text { with 3-4 } \\
\text { carbons of } \\
\text { atom }\end{array}$ & $\begin{array}{c}\text { Farbwerke } \\
\text { Hoechst } \\
\text { Aktiengesells } \\
\text { chaft vormals } \\
\text { Meister } \\
\text { Lucius \& } \\
\text { Bruining, } \\
\text { Frankfurt am } \\
\text { Main, a } \\
\text { corporation of } \\
\text { Germany }\end{array}$ & $\begin{array}{l}\text { S. H. Karl, K. } \\
\text { P. Wilhelm, } \\
1964^{7} \text {. }\end{array}$ & $\begin{array}{l}\text { Condensation of } \\
\text { urea with } \\
\text { aldehydes }\end{array}$ & $\begin{array}{l}\text { there are two steps } \\
\text { of dry condensation } \\
\text { which will take } \\
\text { more time }\end{array}$ & $\begin{array}{l}\text { - Urea fertilizer will be } \\
\text { larger in molecular } \\
\text { weight so that it does } \\
\text { not produce large } \\
\text { amounts of dust. } \\
\text { The product contains } \\
\text { nitrogen soluble in } \\
\text { water and nitrogen, } \\
\text { which is difficult to } \\
\text { dissolve in water. }\end{array}$ \\
\hline $\begin{array}{l}\text { Acrylic Acid } \\
\text { and amylum }\end{array}$ & $\begin{array}{l}\text { Department of } \\
\text { Chemical } \\
\text { Engineering, } \\
\text { Faculty of } \\
\text { Engineering, } \\
\text { Universitas } \\
\text { Diponegoro }\end{array}$ & $\begin{array}{l}\text { A. H. Margi, } \\
\text { T. Septiana S. } \\
\text { Triwiningsih, } \\
\text { Suherman, } \\
2012^{8} \text {. }\end{array}$ & $\begin{array}{l}\text { Fluidized Bed } \\
\text { Spraying } \\
\text { Coating (FBSC) }\end{array}$ & $\begin{array}{l}\text { The bonds that } \\
\text { occur between } \\
\text { urea and } \\
\text { coating agents } \\
\text { tend to be weak } \\
\text { (easily } \\
\text { detached), } \\
\text { resulting in } \\
\text { higher levels of } \\
\text { pollution } \\
\text { Increasing the } \\
\text { bed } \\
\text { temperature } \\
\text { hurts the } \\
\text { efficiency of } \\
\text { the coating due } \\
\text { to the loss of } \\
\text { solutes due to } \\
\text { increased } \\
\text { drying }\end{array}$ & $\begin{array}{c}\text { Polymer coated urea } \\
\text { has a function as a } \\
\text { physical barrier to } \\
\text { the release of urea } \\
\text { into the environment. } \\
\text { The more starch, the } \\
\text { more physical } \\
\text { obstructions on the } \\
\text { surface of the urea, } \\
\text { resulting in a longer } \\
\text { release time and a } \\
\text { lower dissolution } \\
\text { rate. } \\
\text { Starch as a coating } \\
\text { agent for urea can } \\
\text { increase coating } \\
\text { efficiency from } 0 \% \\
\text { wt starch (without } \\
\text { starch) by } 1.6 \% \text { to } \\
14.4 \% \text { at a } \\
\text { concentration of } 2 \% \\
\text { wt starch. } \\
\text { The use of acrylic } \\
\text { can improve the } \\
\text { coating function of } \\
\text { urea }\end{array}$ \\
\hline $\begin{array}{c}\text { Air and } \\
\text { Natural Gas }\end{array}$ & $\begin{array}{l}\text { Center for } \\
\text { Nuclear } \\
\text { Energy } \\
\text { Development } \\
\text { (PPEN) - } \\
\text { BATAN }\end{array}$ & $\begin{array}{c}\text { D. H. Salimy, } \\
2012^{9} \text {. }\end{array}$ & $\begin{array}{l}\text { The steam } \\
\text { reforming gas } \\
\text { process }\end{array}$ & $\begin{array}{l}\text { The ammonia steam } \\
\text { reforming process } \\
\text { requires large } \\
\text { amounts of high- } \\
\text { temperature thermal } \\
\text { energy. }\end{array}$ & $\begin{array}{l}\text { Application of high- } \\
\text { temperature nuclear } \\
\text { reactor heat energy can } \\
\text { save the depletion of } \\
\text { natural gas fossil energy } \\
\text { resources }\end{array}$ \\
\hline
\end{tabular}

\begin{tabular}{|c|c|c|c|c|c|}
\hline $\begin{array}{c}\text { Amylum } \\
\text { polymers and } \\
\text { PVA. }\end{array}$ & $\begin{array}{l}\text { Department of } \\
\text { Chemical } \\
\text { Engineering, } \\
\text { Faculty of } \\
\text { Engineering, } \\
\text { Universitas } \\
\text { Diponegoro }\end{array}$ & $\begin{array}{l}\text { K. Ivanky, W. } \\
\text { R. Tri, S. } \\
\text { Suherman, } \\
2012^{10} \text {. }\end{array}$ & $\begin{array}{l}\text { Urea coating } \\
\text { with polymers }\end{array}$ & $\begin{array}{c}\text { The materials } \\
\text { needed are quite a } \\
\text { lot and a bit } \\
\text { difficult to find }\end{array}$ & $\begin{array}{l}\text { - The analysis method } \\
\text { used is Scanning } \\
\text { Electron Microscopy } \\
\text { (SEM). The } \\
\text { magnification can be } \\
\text { up to 500x } \\
\text { - The dissolution rate } \\
\text { decreases as the } \\
\text { temperature and } \\
\text { concentration are } \\
\text { increased }\end{array}$ \\
\hline
\end{tabular}




\begin{tabular}{|c|c|c|c|c|c|}
\hline $\begin{array}{l}\text { Domestic } \\
\text { waste }\end{array}$ & $\begin{array}{l}\text { United State } \\
\text { Patent } \\
\text { Application } \\
\text { Publication }\end{array}$ & $\begin{array}{c}\text { G. H. Kiss, } \\
2013^{11} \text {. }\end{array}$ & $\begin{array}{c}\text { Gasification } \\
\text { with } \\
\text { thermoselection }\end{array}$ & $\begin{array}{c}\text { Needs high } \\
\text { temperature }(1000- \\
\left.2000^{\circ} \mathrm{C}\right)\end{array}$ & $\begin{array}{l}\text { - } \quad \text { Not producing gas } \\
\text { emissions } \\
\text { - Low cost } \\
\text { - Raw material from } \\
\text { waste }\end{array}$ \\
\hline Air and water & $\begin{array}{l}\text { Center for the } \\
\text { Study of } \\
\text { Nuclear } \\
\text { Energy } \\
\text { Systems } \\
\text { (PKSEN) - } \\
\text { BATAN }\end{array}$ & $\begin{array}{l}\text { D. H. Salimy, } \\
2014^{12} \text {. }\end{array}$ & $\begin{array}{l}\text { Uses nuclear } \\
\text { cogeneration }\end{array}$ & $\begin{array}{l}\text { It is necessary to be } \\
\text { careful in } \\
\text { processing nuclear } \\
\text { energy resources. }\end{array}$ & $\begin{array}{l}\text { The nuclear cogeneration } \\
\text { method is beneficial in } \\
\text { saving natural gas } \\
\text { reserves, but it will also } \\
\text { have implications for } \\
\text { reducing } \mathrm{CO}_{2} \text { emissions. }\end{array}$ \\
\hline $\begin{array}{l}\text { Chitosan, } \\
\text { silica } \\
\text { compound, } \\
\text { and urea }\end{array}$ & $\begin{array}{l}\text { Department } \\
\text { Chemistry } \\
\text { FMIPA } \\
\text { UNESA }\end{array}$ & $\begin{array}{l}\text { L. F. E. } \\
\text { Wulan, } \\
2017^{13} \text {. }\end{array}$ & $\begin{array}{l}\text { Addition of a } \\
\text { chemical } \\
\text { compound }\end{array}$ & $\begin{array}{l}\text { Need a lot of } \\
\text { ingredients }\end{array}$ & $\begin{array}{l}\text { Increase the quality } \\
\text { of fertilizer } \\
\text { - Needs low cost } \\
\text { - Non-toxic and } \\
\text { biodegradable }\end{array}$ \\
\hline $\begin{array}{c}\text { Fly ash, } \\
\mathrm{NaOH}, \text { and } \\
\text { urea }\end{array}$ & $\begin{array}{l}\text { Department of } \\
\text { Chemical } \\
\text { Engineering, } \\
\text { Sriwijaya } \\
\text { State } \\
\text { Polytechnic }\end{array}$ & $\begin{array}{l}\text { M. Yerizam, I. } \\
\text { Purnamasa } \\
\text { ri, A. } \\
\text { Hasan, } \\
\text { R. Junaidi, } \\
2017^{14} \text {. }\end{array}$ & $\begin{array}{l}\text { Coating method } \\
\text { with Fly Ash } \\
\text { Coal and } \mathrm{NaOH}\end{array}$ & $\begin{array}{l}\text { Observation time is } \\
\text { more than } 15 \text { hours }\end{array}$ & $\begin{array}{l}\text { Increase the } \\
\text { effectiveness of urea } \\
\text { use and reduce } \\
\text { environmental } \\
\text { pollution. } \\
\text { Increase the } \\
\text { efficiency of } \\
\text { fertilizer use }\end{array}$ \\
\hline $\begin{array}{l}\text { Waste cooking } \\
\text { oil, Paraffin, } \\
\text { and urea }\end{array}$ & $\begin{array}{l}\text { Department of } \\
\text { Chemical } \\
\text { Engineering, } \\
\text { Faculty of } \\
\text { Engineering, } \\
\text { Uniersitas } \\
\text { Gadjah Mada } \\
\text { Yogyakarta }\end{array}$ & $\begin{array}{l}\text { N. M. } \\
\text { Prakarsa, } \\
2012^{15} \text {. }\end{array}$ & $\begin{array}{l}\text { Urea Fertilizer } \\
\text { Coating Method } \\
\text { with a Mixture } \\
\text { of Waste } \\
\text { Cooking Oil and } \\
\text { Paraffin }\end{array}$ & $\begin{array}{l}\text { - It takes } 48 \\
\text { hours to dry in } \\
\text { the desiccator } \\
\text { To Samples } \\
\text { must be } \\
\text { allowed to } \\
\text { stand for 2-5 } \\
\text { days }\end{array}$ & $\begin{array}{cc}\text { - } & \text { Using low costs } \\
\text { - } & \text { Does not use any } \\
\text { solvents } \\
\text { - Using low } \\
\text { temperatures } \\
\text { - It does not require } \\
\text { complicated } \\
\text { equipment }\end{array}$ \\
\hline
\end{tabular}

\begin{tabular}{|c|c|c|c|c|c|}
\hline $\begin{array}{l}\text { Urea prill } \\
\text { fertilizer }\end{array}$ & $\begin{array}{l}\text { Department of } \\
\text { Chemistry, } \\
\text { Universitas } \\
\text { Sulmatera } \\
\text { Selatan }\end{array}$ & $\begin{array}{c}\text { D. I. } \\
\text { Muthawali, } \\
2018^{16} \text {. }\end{array}$ & $\begin{array}{c}\text { Spectro } \\
\text { photometry }\end{array}$ & $\begin{array}{c}\text { It evaporates easily } \\
\text { and dissolves easily } \\
\text { so that nutrients are } \\
\text { quickly lost }\end{array}$ & $\begin{array}{l}\text { Easy to find at KUD, } \\
\text { fertilizer retailers, } \\
\text { farmer stalls, other } \\
\text { places, Farmers } \\
\text { affordable prices. } \\
\text { Easy to apply. } \\
\text { It can be used for } \\
\text { other purposes, such } \\
\text { as fertilizing ponds, } \\
\text { ration mixtures or } \\
\text { animal feed, glue } \\
\text { mixtures in the wood } \\
\text { industry, and a } \\
\text { variety of fabric } \\
\text { processing materials } \\
\text { in the clothing } \\
\text { industry. }\end{array}$ \\
\hline
\end{tabular}




\begin{tabular}{|c|c|c|c|c|c|}
\hline $\begin{array}{l}\text { Chitosan and } \\
\text { Humic Acid }\end{array}$ & $\begin{array}{l}\text { Department of } \\
\text { Chemistry, } \\
\text { Faculty of } \\
\text { Mathematics } \\
\text { and Natural } \\
\text { Sciences } \\
\text { State, } \\
\text { Universitas } \\
\text { Surabaya }\end{array}$ & $\begin{array}{l}\text { P. M. Andika, } \\
\text { D. K. } \\
\text { Maharani, } \\
2018^{17} \text {. }\end{array}$ & $\begin{array}{l}\text { Slow Release } \\
\text { Fertilizer }\end{array}$ & $\begin{array}{l}\text { - The } \\
\text { manufacturing } \\
\text { process is } \\
\text { relatively } \\
\text { complicate } \\
\text { - Many use } \\
\text { chemicals }\end{array}$ & $\begin{array}{l}\text { Formed urea } \\
\text { fertilizer which has a } \\
\text { higher water } \\
\text { absorption } \\
\text { Chitosan - humic } \\
\text { acid matrix can } \\
\text { increase water } \\
\text { absorption } \\
\text { The element content } \\
\text { contained in urea } \\
\text { fertilizer is not easily } \\
\text { lost }\end{array}$ \\
\hline $\begin{array}{l}\text { Molecularly } \\
\text { Imprinted } \\
\text { Polymers } \\
\text { (MIPs), } \\
\text { grapefruit } \\
\text { from graphite, } \\
\text { and urea }\end{array}$ & $\begin{array}{l}\text { Department of } \\
\text { Chemistry, } \\
\text { Universitas } \\
\text { Sultan Ageng } \\
\text { Tirtayasa }\end{array}$ & $\begin{array}{l}\text { I. Irhamni, } \\
2016^{18} \text {. }\end{array}$ & $\begin{array}{l}\text { Graphene } \\
\text { preparation }\end{array}$ & $\begin{array}{l}\text { It takes a } \\
\text { relatively long } \\
\text { time. } \\
\text { Difficult } \\
\text { immobilization } \\
\text { of bioreceptors } \\
\text { and low } \\
\text { bioreceptor } \\
\text { stability. }\end{array}$ & $\begin{array}{c}\text { - } \quad \text { Easy and cheap } \\
\text { preparation } \\
\text { - } \quad \text { high sensitivity and } \\
\text { selectivity. }\end{array}$ \\
\hline $\begin{array}{c}\text { Urea, } \\
\text { glutaraldehyde } \\
\text {, chitosan, } \\
\text { organic } \\
\text { compound } \\
\text { solvent }\end{array}$ & $\begin{array}{l}\text { Department of } \\
\text { Chemical } \\
\text { Engineering, } \\
\text { Universitas } \\
\text { Sultan Ageng } \\
\text { Tirtayasa }\end{array}$ & $\begin{array}{l}\text { R. S. D. } \\
\text { Lestari, } \\
2020^{19} \text {. }\end{array}$ & Cross-linking & $\begin{array}{l}\text { The materials } \\
\text { used are } \\
\text { dangerous } \\
\text { The material } \\
\text { used is only } \\
\text { available in the } \\
\text { laboratory }\end{array}$ & $\begin{array}{l}\text { It becomes more } \\
\text { effective as a } \\
\text { function of fertilizer } \\
\text { Easy and cheap } \\
\text { preparation }\end{array}$ \\
\hline $\begin{array}{l}\text { Sulfur, Starch, } \\
\text { PVA, POP, } \\
\text { Molasses, } \\
\text { Gelatin, and } \\
\text { Paraffin Wax }\end{array}$ & $\begin{array}{l}\text { Department of } \\
\text { Chemical } \\
\text { Engineering, } \\
\text { Department of } \\
\text { Agronomy, } \\
\text { Research and } \\
\text { Development } \\
\text { Departement, } \\
\text { and } \\
\text { Department of } \\
\text { Evirontmental } \\
\text { Sciences, } \\
\text { Pakistan }\end{array}$ & $\begin{array}{c}\text { B. Beig, M. B. } \\
\text { Niazi, Z. } \\
\text { Jahan, E. } \\
\text { Pervaiz, } \\
\text { G. Abbas } \\
\text { Shah, M. } \\
\text { Ul Haq, M. } \\
\text { I Zafar, } \\
\text { M. Zia, } \\
2020^{20} \text {. }\end{array}$ & $\begin{array}{l}\text { Coating Use } \\
\text { Organic and } \\
\text { Inorganic }\end{array}$ & $\begin{array}{l}\text { Because the } \\
\text { SEM analysis } \\
\text { results cannot } \\
\text { determine } \\
\text { whether coated } \\
\text { urea is efficient } \\
\text { or not, other } \\
\text { tests are needed } \\
\text { that use a lot of } \\
\text { time not to be } \\
\text { produced in a } \\
\text { brief period. }\end{array}$ & $\begin{array}{l}\text { - The coated urea is } \\
\text { tested directly on } \\
\text { plants such as } \\
\text { spinach } \\
\text { Materials that used } \\
\text { for urea coating are } \\
\text { measly so that it will } \\
\text { save costs }\end{array}$ \\
\hline
\end{tabular}

\section{Conclusion}

Based on the methods mentioned, the urea fertilizer coating method with fly ash and $\mathrm{NaOH}$ was chosen to be the most effective than other methods. This method can increase the effective utilization of urea, reduce environmental pollution, relatively more straightforward, the raw material of this method more affordable and spread widely in the market. Also, fly ash has excellent potential in agriculture due to its efficacy in modifying soil health and crop performance. The release of modified urea is more extended than standard urea with the same weight. The time observed is 12 hours. $5 \mathrm{~g}$ of urea has been used up, while much-modified urea remains. This modified urea's release time is more than 15 hours with a weight of $1 \mathrm{~g}$ and the water release time reaches 16 minutes.

\section{References}

1- J. Albari, Peranan Pupuk Nitrogen dan Fosfor pada Tanaman Kelapa Sawit (Elaeis guineensis Jacq.) Belum Menghasilkan Umur Tiga Tahun, Buletin Agrohorti, 2018, 6(1), 42-49.

2- S. K. De Datta, Advances in Soil Fertility Research and Nitrogen fertilizer Management for Lowland Rice, Providing Efficiency of Nitrogen, 1987, 27-41.

3- G. G. L. Gopar, M. A. L. Villanueva, D. E. R. García, Pueblos ferroviarios símbolos de la industrialización. Interpretación de vivencias para rescatar la historia. Caso El Parián Oaxaca, Cuerpos Académicos de la Universidad Autónoma "Benito Juárez" de Oaxaca, 2018, 23.

4- M. K. Dazmiri, M. V. Kiamahalleh, A. Dorieh, A. Pizzi, Effect of initial F/U molar ratio in Urea- 
formaldehyde resins synthesis and its influence on the performance of medium density fiberboard bonded with them, International Journal of Adhesion and Adhesives, 2019, 95, 102440.

5- A. Dorieh, N. O. Mahmoodi, M. Mamaghani, A. Pizzi, M. Mohammadi Zeydi, Effect Of Different Acid During The Synthesis of UreaFormaldehyde Adhesives, Journal of Applied Polymer Science, 2018, 136(14), 47256.

6- T. Guru, R. Thatikunta, N. Reddy, S. N. Reddy, Crop Nutrition Management with Nano fertilizers, International Journal of Environmental, 2015, 1(1), 4-6.

7- S. H. Karl, K. P. Wilhelm, Process For The Manufacture Of Granular Urea-Aldehyde Fertilizer, Germany : Farbwerke Hoechst Aktiengesellschaft vormals Meister, Lucius \& Bruining, Frankfurt am Main, a corporation of Germany, Patent No. 3,326,665, 1964.

8- A. H. Margie, T. Septian, Pembuatan Urea Pelepasan Lepas Lambat melalui Pelapisan Dengan Amilum-Acrylic, Jurnal Teknologi Kimia dan Industri, 2012, 1, 229-236.

9- D. H. Salimy, Aplikasi Energi Panas Nuklir Temperatur Tinggi Pada Pabrik Pupuk Urea, Jurnal Pengembangan Energi Nuklir, 2012, 14. Doi: 10.17146/jpen.2012.14.1.1478.

10-K. Ivanky, W. R. Tri, S. Suherman, Pembuatan Urea Pelepasan terkendali Melalui Pelapisan Dengan Amilum Menggunakan Teknologi Fluidized Bed Spray, Jurnal Teknologi Kimia dan Industri, 2012, 1, 64-68.

11-G. H. Kiss, Method of Manufacturing Urea From Refuse Preferably Domestic Waste of Any Composition. U.S. Patent No. 9,458,099, 2016.

12-D. H. Salimy, Aplikasi Kogenerasi Nuklir Untuk Dekomposisi Air Pada Konversi $\mathrm{CO}_{2}$ Menjadi Pupuk Urea, Jurnal Pengembangan Energi Nuklir, 2014, 16, 85-94.

13-L. F. E. Wulan, Pemanfaatan Kitosan-Silika sebagai Matriks pada Pembuatan Pupuk Urea Slow Release, UNESA Journal of Chemistry, 2017, 6 .

14-M. Yerizam, I. Purnamasari, A. Hasan, R. Junaidi, Modifikasi Urea Menjadi Pupuk Lepas Lambat Menggunakan Fly Ash Batubara dan NaOH Sebagai Binder, Jurnal Teknik Kimia, 2017, 23, 226-229.

15-N. M. Prakarsa, Pelepasan Pada Pupuk Urea Menggunakan Campuran Minyak Jelantah dan Parafin Dengan Metode Slow Release Fertilizer, Yogyakarta : Universitas Gadjah Mada, 2012.

16-D. I. Muthawali, Penetapan Kadar Biuret Dalam Pupuk Urea Prill dengan Metode Spektrofotometri, Saintek ITM , 2018, 31.

17-P. M. Andika, D. K. Maharani, Penentuan Daya Penyerapan Air (Swelling) Pupuk Urea (Slow
Release Fertilizer) Dalam Matriks Kitosan-Asam Humatdetermination Swelling Of Urea Fertilizer (Slow Release Fertilizer) In The Matrix Of Chitosan-Humic Acid. UNESA Journal of Chemistry, 2018, 7.

18-I. Irhamni, Preparasi Moleculary Imprinted Polymers Sebagai Adsorben Untuk Urea dan Kreatinin, EduChemia (Jurnal Kimia dan Pendidikan), 2016, 1(2), 189-203.

19-R. S. D. Lestari, J. Jayanudi, Preparasi dan Karakterisasi Kitosan Tertaut Silang Glutaraldehida sebagai Matrik Pupuk Urea, Jurnal Integrasi Proses, 2020, 9(2), 27-33.

20-B. Beig, M. B. Niazi, Z. Jahan, E. Pervaiz, G. Abbas Shah, M. U1 Haq, M. I Zafar, M. Zia, Slow-Release Urea Prills Developed Using Organic and Inorganic Blends in Fluidized Bed Coater and Their Effect on Spinach Productivity, Sustainability, 2020, 12, 5944.

21-A.B.D. Nandiyanto, Kurnia, D. Sofiani, D. C. Kusuma, F. Fitriani, I. P. Rahayu, A. Rusli, A. Purnamasari, A. S. Wiryani, A. Rahim, Pengantar Kimia Industri: Penerapan Ilmu Kimia Menjadi Produk Kimia Skala Besar, Bandung: UPI Press, 2016.

22-E. R. Riegel, J. A. Kent, Handbook of Industrial Chemistry, Springer, 2007.

23-E. Chiellini, A. Corti, R. Solar, Biodegradation of poly (vinyl alcohol) based blow films under different environment conditions, Polym. Degrad. Stability, 1999, 64(2), 305-312.

24-I. Kroschwitz, M. Howe-Grant, Kirk-Othmer encyclopaedia of chemical technology, Vols. 3 10, Angewandte Chemie-English Edition, 1995, 34(22), 2564-2564.

25-A. Rosma, P. Laras, Industry Pharmaceuticals: Chitosan as an Alternative Replacement Gelatin Capsule on Shell, Journal of Medical and Bioengineering, 2016, 5.

26-A. L . Underwood, R.A. Day, JR. Analisis Kimia Kuantitatif. Jakarta : Erlangga, 2001.

27-J. Basset, Vogel: Buku Ajar Kimia Analisis Kuantitatif Anorganik, Jakarta : EGC Kedokteran, 1994.

28-A. Firdas, M. Dian, Pelepasan Nitrogen Pada Pupuk Slow Release Urea dengan Menggunakan Matriks Kitosan - Bentonit, UNESA Journal of Chemistry, 2017, 6, 68-72.

29-H. A. Tsai, M. J. Syu, Preparation of Imprinted Poly(tetraethoxysilanol) Sol-Gel for The Specific Uptake of Creatinine, Chemical Engineering Journal, 2011, 168, 1369-1376.

30-K. S. Patel, M. B. Patel, Preparation and Evaluation of Chitosan Microspheres Containing Nicorandil, International journal of pharmaceutical investigation, 2014, 4(1), 32. 